\title{
Identification, sequencing, and cellular localization of hepcidin in guinea pig (Cavia porcellus)
}

\author{
Peggy Schwarz, Pavel Strnad, Nadine Singer, Franz Oswald, Robert Ehehalt ${ }^{1}$, \\ Guido Adler and Hasan Kulaksiz
}

Division of Gastroenterology, Department of Internal Medicine, University Hospital Ulm, Albert-Einstein-Allee 23, D-89081 UIm, Germany

${ }^{1}$ Division of Gastroenterology, Department of Internal Medicine, University Hospital Heidelberg, Im Neuenheimer Feld 410, D-69120 Heidelberg, Germany

(Correspondence should be addressed to H Kulaksiz; Email: hasan.kulaksiz@uniklinik-ulm.de)

\begin{abstract}
Hepcidin, a cysteine-rich peptide hormone with antimicrobial and iron-regulatory activity, plays a central role in regulating iron metabolism during inflammation, hypoxia, iron deficiency, and iron overload. The aim of this study was to isolate and sequence the guinea pig hepcidin gene and show peptide's tissue distribution to identify the guinea pig as good animal model to study the regulation and function of hepcidin. The guinea pig hepcidin cDNA contains a $252 \mathrm{bp}$ open reading frame encoding for an 83 amino acid protein with eight highly conserved cysteine residues. Phylogenetic analyses showed that guinea pig hepcidin was more related to human and chimpanzee than to rodents like mouse or rat. RT-PCR studies revealed that hepcidin mRNA was most abundant in liver, less ample in pancreas, heart, and kidney and not detectable in lung and biliary
\end{abstract}

system. Western blot analyses showed a distinct immunoreactive band of $\sim 8 \mathrm{kDa}$, consistent with the predicted size of prohepcidin, and revealed that guinea pig hepcidin protein is synthesized predominantly in the liver, and with lower expression in kidney, heart, and pancreas. Immunohistochemical studies showed hepcidin predominantly at the basolateral membrane domain of hepatocytes in periportal regions. In pancreas, hepcidin immunoreactivity was confined to endocrine islets of Langerhans, while hepcidin was seen in tubules, but not in the glomeruli in the kidney. Our data identify guinea pig as a convenient model organism to study the role of hepcidin, given the remarkable sequence similarity and tissue distribution pattern largely identical to human.

Journal of Endocrinology (2009) 202, 389-396

\section{Introduction}

The peptide hormone, hepcidin, is the major regulator of iron metabolism. It was first isolated from human serum and urine (Krause et al. 2000, Park et al. 2001). Subsequently, a number of hepcidin genes were identified, both from mammals like mouse (Pigeon et al. 2001, Ilyin et al. 2003), rats, and dogs (Fry et al. 2004) and lower-vertebrates like amphibians (Hu et al. 2008) and fishes (Shike et al. 2002, 2004, Douglas et al. 2003, Bao et al. 2005, Chen et al. 2005, 2007, Hirono et al. 2005, Kim et al. 2005, 2008, Cuesta et al. 2007). All isolated hepcidin sequences share a highly homologous amino acid sequence and evolutionary conserved cysteine residue pattern, which are characteristic for antimicrobial peptides, leading to the formation of three to four disulfide bridges that might be necessary for the antimicrobial function of hepcidin. Like most of the antimicrobial peptides, hepcidins are amphiphilic and contain both cationic and hydrophobic surfaces respectively. This structure allows antimicrobial peptides to insert into biological membranes to cause lysis of pathogens like bacteria and fungi (Hancook \& Lehrer 1998). As an acute-phase protein (Nemeth et al. 2003), hepcidin is an important component of the host innate immune response. During bacterial infection or inflammation, macrophages produce more interleukin-6 (IL-6). IL-6 and bacterial lipopolysaccharide induce hepatic hepcidin gene expression significantly (Pigeon et al. 2001, Nicolas et al. 2002a, Nemeth et al. 2003, 2004a).

Subsequent studies revealed that apart from the antimicrobial activity and its anti-inflammatory role, hepcidin exhibits iron-regulatory functions. Overexpression of the peptide hormone in hepatic adenomas caused anemia in humans (Weinstein et al. 2002). Mice overexpressing hepcidin develop severe anemia (Nicolas et al. 2002b), whereas lack of hepcidin causes iron overload in the liver, pancreas, and the heart (Nicolas et al. 2001) similar to iron overload patterns in patients suffering from hereditary hemochromatosis (Roetto et al. 2003). Based on these results, hepcidin was identified as the central regulator of iron metabolism (Ganz 2003, Kulaksiz et al. 2004). The peptide binds to ferroportin inducing its internalization and degradation (Nemeth et al. 2004b) and thereby inhibits the release of iron from the basolateral membrane of enterocytes into the hepatic portal system as well as from macrophages into the systemic circulation 
(Ganz 2003). Accordingly, elevated hepcidin concentration seen in pathological conditions (e.g. infection, inflammation) causes reduced iron availability for growing and invading bacteria and/or tumor cells (Vyoral \& Petrak 2005).

While the data on the expression, regulation, and function of hepcidin in different species and diseases are accumulating, the precise molecular action of hepcidin is still only incompletely understood. Here, we report the cloning and sequencing of full-length guinea pig hepcidin cDNA, determination of hepcidin tissue distribution, and identification of the guinea pig as a convenient animal model for studying hepcidin and iron metabolism.

\section{Materials and Methods}

\section{Tissue sources}

Four male guinea pigs (strain HsdPoc:DH, $200 \mathrm{~g}$ ), obtained from Harlan Winkelmann (Borchen, Germany), used in these experiments were cared for in accordance with the criteria outlined in the European Convention for the Protection of Vertebrate Animals. Animals were maintained in a temperature- and light-controlled environment and were given free access to tap water and food. Guinea pigs were killed by $\mathrm{CO}_{2}$ inhalation. Small tissue pieces from liver, heart, pancreas, kidney, gall bladder, bile duct, and lung were promptly removed. Probes were submerged into RNAlater Stabilization Reagent (Qiagen) and kept at $-20{ }^{\circ} \mathrm{C}$ for RNA isolation or snap frozen in liquid nitrogen and stored at $-80^{\circ} \mathrm{C}$ for further biochemical analyses. Alternatively, specimens were fixed in $4 \%(\mathrm{w} / \mathrm{v})$ paraformaldehyde for subsequent immunohistochemical staining.

\section{$R N A$ preparation, isolation, and $c D N A$ synthesis}

Total RNAs were isolated using the RNeasy Mini Kit (Qiagen), according to the kit manual. Concentration of isolated RNAs were determined with a spectrophotometer (Biophotometer, Eppendorf, Hamburg, Germany), and $2 \mu \mathrm{g}$ total RNA was used to generate cDNAs with the SuperScript III Reverse Transcriptase kit (Invitrogen), following the manual instructions.

\section{Cloning and sequencing of the guinea pig hepcidin $m R N A$}

Based on sequence homologies between the published hepcidin cDNA sequences of human (AF309489), mouse (hepcidin 1, AF297664; hepcidin 2, NM_183257), rat (AF344185), pig (AF516143), chimpanzee (NM_00110 9693), and dog (AY772532) degenerative primers in the neighboring regions of start and stop codon were synthesized (Biomers, Ulm, Germany) as follows: forward primer, $5^{\prime}$-cacgatggcactvagcwcbc- $3^{\prime}$; reverse primer $5^{\prime}$-ctaygtywtg$\operatorname{cagc}-3^{\prime}(v=a / c / g, w=a / t, b=t / c / g$ and $y=c / t)$.
PCR was performed in a $50 \mu \mathrm{l}$ final volume containing $1 \mu l$ guinea pig liver cDNA, $100 \mathrm{pmol} / \mu \mathrm{l}$ of each forward and reverse primer, $10 \mathrm{mmol} / 1 \mathrm{dNTP} \operatorname{mix}$ (PeqLab, Erlangen, Germany), and $2.5 \mathrm{U}$ taq DNA polymerase with $1 \mathrm{mmol} / 1$ $\mathrm{MgCl}_{2}$ and the supplied buffer (Fermentas, St Leon-Rot, Germany). An initial denaturation step $\left(10 \mathrm{~min}\right.$ at $\left.94{ }^{\circ} \mathrm{C}\right)$ was followed by 45 amplification cycles, each containing denaturation $\left(94^{\circ} \mathrm{C}\right.$ at $30 \mathrm{~s}$ ), annealing (ramp from 48 to $64{ }^{\circ} \mathrm{C}$ at $\left.30 \mathrm{~s}\right)$, and elongation $\left(72^{\circ} \mathrm{C}\right.$ at $\left.1 \mathrm{~min}\right)$ as well as a final extension step $\left(72^{\circ} \mathrm{C}, 10 \mathrm{~min}\right)$. Final PCR products were electrophorized on $1.5 \%(\mathrm{w} / \mathrm{v})$ agarose gel; bands of the expected size were extracted and purified (QIAquick Gel Extraction kit, Qiagen). The products were cloned into pCR2.1 TOPO TA vector (Invitrogen) and plasmids were amplified after transformation into Escherichia coli INV $\alpha \mathrm{F}^{\prime}$ strain (Invitrogen). Isolated plasmid DNA (NucleoSpin Plasmid kit, Macherey-Nagel, Düren, Germany) was digested with restriction enzyme EcoRI (New England Biolabs, Ipswich, MA, USA) to check for correct transformation and was sequenced (Eurofins MWG Operon, Martinsried, Germany). Sequence results were then compared with published hepcidin cDNA sequences from other species available in the National Center for Biotechnology Information (NCBI) GenBank database.

\section{Phylogenetic studies}

Alignments and clustalW analyses (Thompson et al. 1994) were performed using Biology WorkBench 3.2 (University of Illinois) and hepcidin amino acid sequences available on NCBI databases (human, NP_066998; mouse hepcidin 1, NP_115930; mouse hepcidin 2, NP_899080; rat, NP_445921; pig, NP_999282; chimpanzee, NP_00110 3163; and dog, NP_001007141). Signal peptides in the deduced guinea pig amino acid sequence were predicted using the Signal P 3.0 Program (Bendtsen et al. 2004). A phylogenetic tree of guinea pig hepcidin amino acid sequence and its counterparts were conducted by the neighbor-joining method (Saitou \& Nei 1987) and analyzed with Mega 4 (Tamura et al. 2007).

\section{Quantitative RT-PCR analyses of tissue distribution}

To perform the tissue expression studies, the identified guinea pig hepcidin cDNA sequence was utilized to design specific primers (forward primer: $5^{\prime}$-caacacagctgaagccaagg- $3^{\prime}$, reverse primer: $5^{\prime}$-gtcttgcagcatatcccacac $\left.-3^{\prime}\right)$. Guinea pig actin was used as an endogenous control (forward primer: $5^{\prime}$-ctgacagactacctcatgaag- $3^{\prime}$, reverse primer: $5^{\prime}$-ggaaccgctcattgccaatg- $\left.3^{\prime}\right)$.

Real-time RT-PCR were performed in a total volume of $10 \mu \mathrm{l}$ containing $0 \cdot 1 \mu \mathrm{l}$ tissue cDNA, $10 \mathrm{pmol} / \mu \mathrm{l}$ of each gene-specific primer, and $5 \mu \mathrm{l}$ master mix solution $\left(\mathrm{RT}^{2}\right.$ Real Time SYBR Green/Rox PCR Master Mix, SABioscience, Biomol, Hamburg, Germany). The reactions 
were carried out in 96-well plates using the real-time SDS 7500 Fast RT-PCR machine (Applied Biosystems, Darmstadt, Germany).

After the initial denaturation $\left(95^{\circ} \mathrm{C}, 10 \mathrm{~min}\right), 45$ amplification cycles were performed, each consisting of a denaturation $\left(95^{\circ} \mathrm{C}, 15 \mathrm{~s}\right)$ and an annealing plus elongation step $\left(60^{\circ} \mathrm{C}, 1 \mathrm{~min}\right)$. Subsequently, a melt curve assay was employed to determine the specificity of amplified PCR products. Results were analyzed with the 7500 Fast System SDS Software (Applied Biosystems).

\section{Hepcidin antibodies}

From the published prohepcidin sequence (Krause et al. 2000, Pigeon et al. 2001), the peptide hepcidin-(28-47) was synthesized as C-terminal amide using a standard Fmoc (N-alpha-(9-fluorenylmethyloxycarbonyl)) protocol (Kulaksiz et al. 2002). Peptides were coupled to keyhole limpet hemocyanin using $m$-maleimidobenzoyl- $N$ hydroxysuccinimide ester, and six SPF rabbits (Charles River-Iffa Credo, Wilmington, MA, USA) were immunized with peptide conjugate (Eurogentec, Seraing, Belgium). The antibodies EG(2)-HepN and EG(5)-HepN (directed against prohepcidin-(28-47)) have been generated and characterized (Kulaksiz et al. 2004, 2005, 2008, Fein et al. 2007, Merle et al. 2007).

\section{Western blot analysis}

Frozen tissue samples were homogenized with liquid nitrogen-cooled mortar and pestle and transferred into protein extraction buffer $(0.35 \mathrm{~mol} / 1 \mathrm{SDS}, 1.4 \mathrm{~mol} / \mathrm{l}$ Tris$\mathrm{HCl} \mathrm{pH} 6.8$ and, $1.3 \mathrm{~mol} / 1$ glycerin) containing protease inhibitor cocktail 'complete' (Roche Applied Science). After centrifugation $\left(4^{\circ} \mathrm{C}, 10600 \mathrm{~g}, 10 \mathrm{~min}\right)$, the supernatants were stored at $-80^{\circ} \mathrm{C}$. Western blot analyses were performed as described elsewhere (Kulaksiz et al. 2004, 2005, 2008, Pietrangelo et al. 2005, Fein et al. 2007, Merle et al. 2007) with minor changes. Briefly, probes (each $50 \mu \mathrm{g}$ protein) were separated electrophoretically using a $16.5 \%$ $(\mathrm{w} / \mathrm{v})$ tricine-SDS-polyacrylamide gel and transferred onto hydrophobic polyvinylidene fluoride-based membranes (Pall, Porthmouth, UK) by wet blotting in a "criterion blotting system' (Bio-Rad Laboratories GmbH). Membranes were incubated overnight with specific hepcidin antibodies (dilution 1:1000, see above) and washed with Tris buffered saline $(10 \mathrm{mmol} / 1$ Tris- $\mathrm{HCl}(\mathrm{pH} 8 \cdot 0), 150 \mathrm{mmol} / 1 \mathrm{NaCl})$ containing $0 \cdot 1 \% \quad(\mathrm{v} / \mathrm{v})$ Tween 20. Immunoreactive proteins were visualized after incubation with peroxidase conjugated goat anti-rabbit antibody (Sigma-Aldrich; dilution 1:10 000) using ECL Western Blotting Detection reagents (GE Healthcare, Munich, Germany). Actin was used as loading control (antibody from Sigma-Aldrich; dilution 1:10 000).

\section{Immunohistochemistry}

Immunohistochemistry staining was performed as described elsewhere (Kulaksiz et al. 2004, 2005, 2008, Fein et al. 2007, Merle et al. 2007). Briefly, paraformaldehyde-fixed samples were dehydrated, embedded in paraffin, and cut into $5 \mu \mathrm{m}$ thin sections. Hepcidin tissue distribution was visualized with antibody EG(2)-HepN (Kulaksiz et al. 2004, 2005, 2008, Fein et al. 2007, Merle et al. 2007), and biotinylated anti-rabbit IgG (Jackson Immunoresearch, West Grove, PA, USA) by incubating the sections in $0.7 \mathrm{mmol} / 1$ diaminobenzidine hydrochloride $/ 0 \cdot 002 \%(\mathrm{v} / \mathrm{v}) \mathrm{H}_{2} \mathrm{O}_{2}$ in $0.05 \mathrm{~mol} / 1$ Tris- $\mathrm{HCl}(\mathrm{pH} 7 \cdot 6)$.

\section{Results}

\section{Cloning and sequencing of guinea pig hepcidin $c D N A$}

Given the fact that liver represents the major hepcidinproducing organ, we generated cDNA from guinea pig liver tissue and subjected it to PCR amplification using degenerative primers based on the previously published hepcidin sequences. The resulting fragments ranging from 200 to $500 \mathrm{bp}$ were purified from preparative agarose gel and cloned into pCR2.1 TOPO vector for sequencing. The complete nucleotide sequence of the cloned guinea pig hepcidin cDNA and the deduced amino acid sequence were determined (Fig. 1). The cDNA fragment was $252 \mathrm{bp}$ in length and contained an open reading frame for an 83 amino acid peptide. Alignment studies revealed that the guinea pig hepcidin shares $80 \%$ identity with human hepcidin nucleotide sequence, while identity of both mouse hepcidins was only $67 \%$. Compared with rat, chimpanzee, dog, and pig, the guinea pig hepcidin exhibited identities of $65,81,76$, and $74 \%$ respectively.

Using the identified cDNA sequence as a query in BLAT (BLAST-like alignment tool) (Kent 2002) on UCSC guinea pig genome browser (Karolchik et al. 2008; http://genome. ucsc.edu/), we found a putative hepcidin gene on chromosome 56. The $1175 \mathrm{~kb}$ genomic structure of guinea pig hepcidin contained three exons and two introns (Fig. 1). The first exon encoding the entire preregion and part of the peptides' proregion is followed by the large intron 1 ( $846 \mathrm{bp}$ in guinea pig) and exon 2, which encodes for the remaining part of prohepcidin. The subsequently located intron 2 is small (in guinea pig $77 \mathrm{bp}$ ) and is followed by the mature peptide encoding exon 3.

\section{Molecular phylogenetic analysis of guinea pig hepcidin}

Based on the cDNA sequence of guinea pig hepcidin, the amino acid sequence of the 83 amino acid prepropeptide was deduced. In the guinea pig preprohepcidin, a 23 amino acid signal sequence was located at the $\mathrm{N}$-terminus. A tentative $\mathrm{RX}(\mathrm{K} / \mathrm{R}) \mathrm{R}$ motif for propeptide convertase (Nakayama 1997) was identified in the C-terminal region of the resulting prohepcidin, suggesting a cleavage of prohepcidin between 

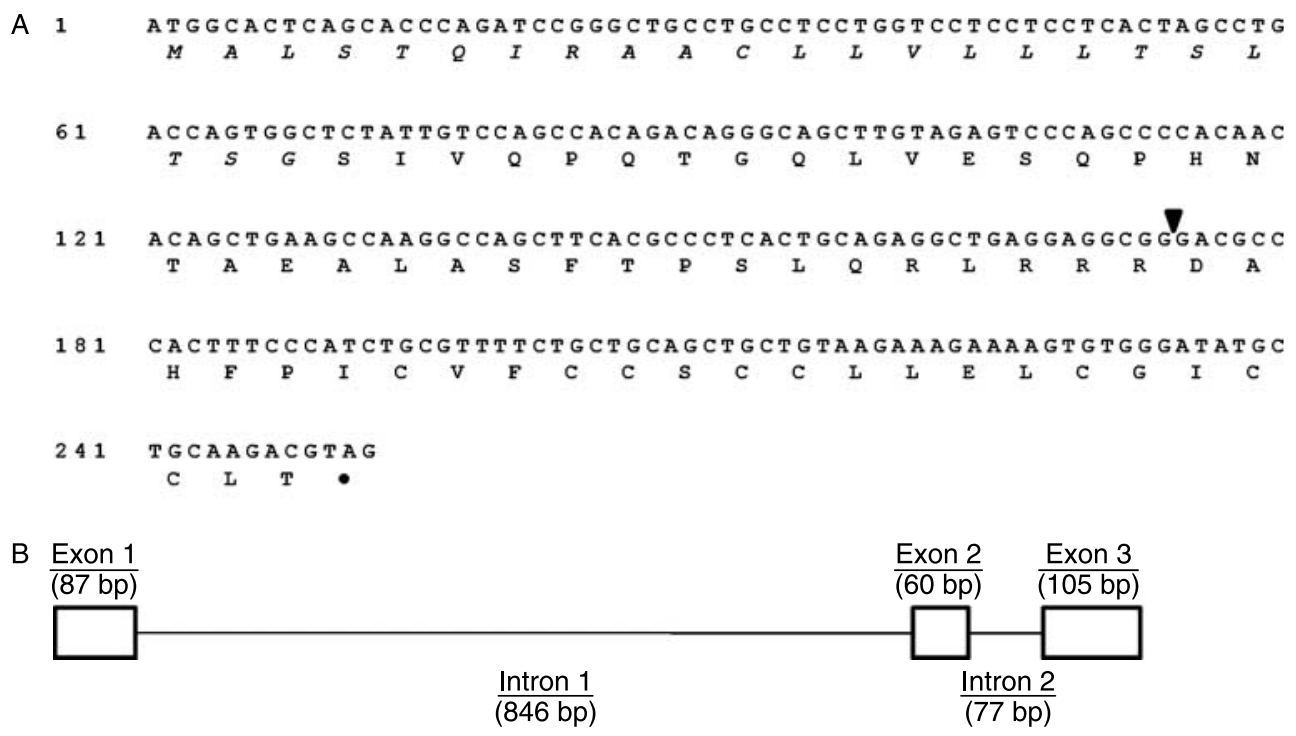

Figure 1 Sequence and structure of the identified guinea pig hepcidin. (A) Nucleotide and predicted amino acid sequence of guinea pig hepcidin mRNA. Amino acids 1-23 belonging to the $\mathrm{N}$-terminal signal peptide are in italics. The cleavage site for propeptide convertase is indicated by the arrow head. (B) Genomic structure and organization of guinea pig hepcidin (proportional reflection). Rectangles represent exons; introns are represented by lines.

residues $\operatorname{Arg}(58)$ and $\operatorname{Asp}(59)$. The resulting 25 amino acid mature, biological active protein (hepcidin-25) contains eight C-terminal cysteine residues.

Comparisons of guinea pig hepcidin complete amino acid sequence with the counterparts from other species obtained from NCBI were performed using clustalW analysis (Biology WorkBench 3.2, University of Illinois). Analyses showed that similarities between preprohepcidin from guinea pig and human or chimpanzee were remarkably high (65 and 66\% respectively), but the guinea pig peptide shared only 50\% identity with both mouse hepcidins (hepcidin 1 and 2), while it exhibited 50, 59, and 62\% homology with hepcidin peptides of rat, dog, and pig respectively (Fig. 2).

Analyzing the sequences of biological active hepcidins showed that guinea pig sequence shared 64\% homology with amino acid sequence from human, mouse (both, hepcidin 1 and 2), chimpanzee, pig, and dog, while rat amino acid sequence shared only $60 \%$ identity with guinea pig hepcidin25 (Fig. 2). Analysis of phylogenetic relationship of hepcidin's 83 amino acid sequence confined that guinea pig preprohepcidin is more related to human sequence than to that of mouse or rat (Fig. 2).

\section{Tissue distribution of guinea pig hepcidin $m R N A$}

Tissue expression analyses were performed by quantitative RT-PCR (Fig. 3). In the guinea pig, hepcidin transcript was highly abundant in the liver, while pancreas displayed $\sim 10$ $\times$ lower mRNA levels. In heart and kidney, there was only low hepcidin expression, while no appreciable hepcidin mRNA was detectable in lung and biliary system.

\section{Tissue distribution of guinea pig hepcidin protein}

To assess hepcidin expression on protein level, western blot analyses using region-specific antibodies against the $\mathrm{N}$-terminal of hepcidin were performed on liver, pancreas, heart, and kidney tissues. In probes of liver, the hepcidin antibodies identified the peptide at $8 \mathrm{kDa}$ (Fig. 4), consistent with the size of human prohepcidin (Kulaksiz et al. 2004). An immunoreactive band of same size was detected in probes of kidney and heart, but only a weak band was identified in pancreas. The $20 \mathrm{kDa}$ band in the liver observed before (Kulaksiz et al. 2004) and suggested to be the dimeric form of hepcidin is absent in our present western blots, probably due to new protocol.

\section{Cellular localization of hepcidin in guinea pig liver, pancreas} and kidney

Immunohistochemical staining using region-specific hepcidin antibody EG(2)-HepN showed localization of the peptide in liver, pancreas, and kidney (Fig. 5). In the liver, hepcidin immunostaining was located in hepatocytes. The distribution showed a predominant staining in the periportal zones, which decreased from portal triads towards the central veins. At the subcellular level, hepcidin was localized at the basolateral membrane domain of guinea pig hepatocytes. Staining of guinea pig pancreatic tissue sections revealed a distinct cytoplasmatic immunoreactivity in endocrine cells within Langerhans islets. Exocrine gland cells did not show a specific hepcidin staining. In the kidney, we detected the guinea pig hepcidin peptide in the cytoplasma of tubule epithelial cells; no staining was observed in glomeruli. 

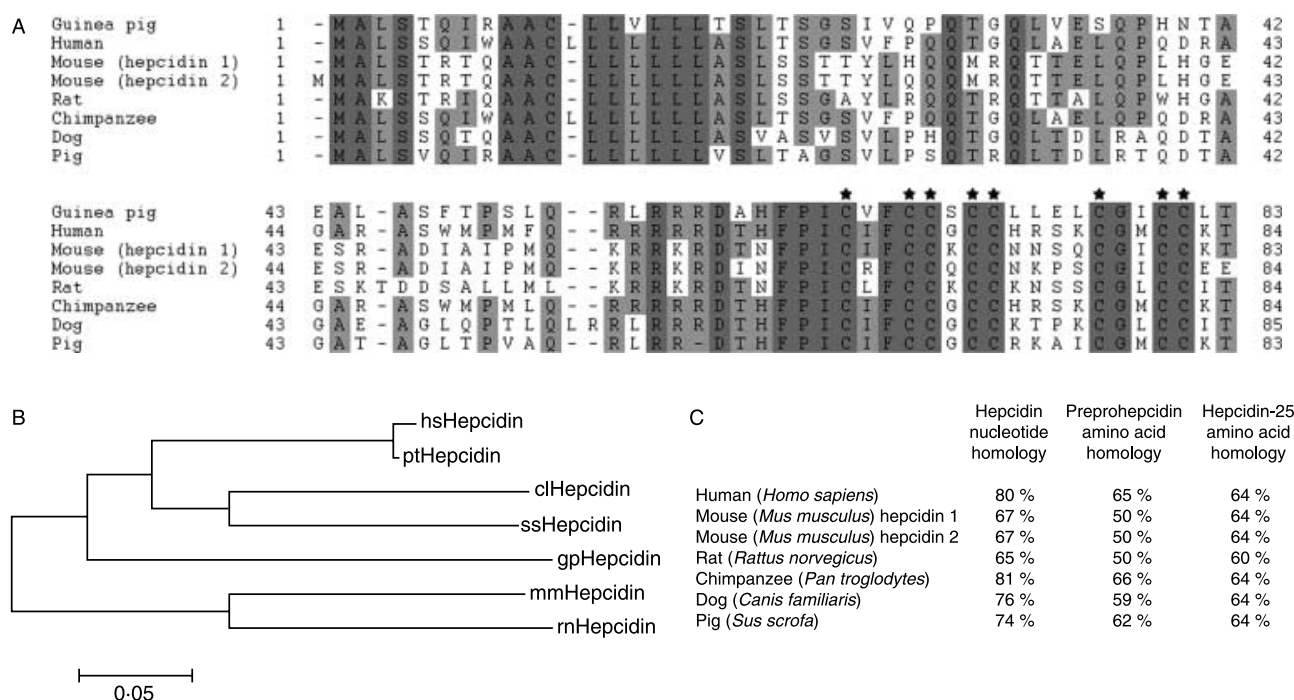

Figure 2 Alignment of guinea pig hepcidin amino acid sequence with other mammals (A) and phylogenetic analysis (B). (A) Guinea pig hepcidin predicted amino acid sequence in comparison with hepcidin amino acid sequences of human, mouse, rat, chimpanzee, dog, and pig. The eight cysteine residues at the C-terminal end are marked (asterisk). Fully conserved and similar (conserved in five to seven of the eight species) residues are indicated in dark and light gray respectively. GenPept accession numbers of the aligned sequences for hepcidin are for human (Homo sapiens, NP_066998), mouse (Mus musculus Hepcidin 1, NP_115930; Hepcidin 2, NP_899080), rat (Rattus norvegicus, NP_445921), chimpanzee (Pan troglodytes, NP_001103163), dog (Canis familiaris, NP_001007141), and pig (Sus scrofa, NP_999282). (B) Phylogenetic analysis of guinea pig hepcidin and other mammals. Constructions are performed based on homology sequences calculated from the respective preprohepcidins. The tree was constructed using a neighbor-joining method and nodes indicate the percentage of bootstrapping after 1000 replications. The scale bar is $0 \cdot 05$, which refers to percentage of divergence. (C) Resume of alignment studies comparing guinea pig hepcidin nucleotide sequence, amino acid sequence of full-length preprohepcidin, and amino acid sequence of biological active hepcidin-25 with counterparts of the indicated species.

\section{Discussion}

In most of the mammalian species so far examined, one hepcidin gene was identified. Until today, only mouse was found to express two genes encoding for hepcidin 1 and hepcidin 2 respectively. In our study, we identified a $252 \mathrm{bp}$ fragment, representing the guinea pig cDNA; we found no additional hepcidin isoform in this species. The genomic structure of guinea pig hepcidin, identified by BLAT alignment (Kent 2002), was similar to the one found in human, mouse (Ilyin et al. 2003), and rat. Studies revealed only one putative hepcidin gene in guinea pig. The BLAT analyses underlined our results that there is only one hepcidin isoform in guinea pig, which may be beneficial in comparative studies, since the exact function and regulation of hepcidin 2 in mice are not yet clarified.

Similar to all hepcidin proteins analyzed so far, the guinea pig hepcidin amino acid sequence contains eight cysteine residues located at conserved positions, thereby belonging to cysteine-rich $\beta$-defensins.

The identified guinea pig hepcidin peptide contains a prohormone convertase recognition sequence, which was shown in humans to be necessary to yield the mature protein (Valore \& Ganz 2008). In both guinea pig and humans, the mature protein is 25 amino acids long.
Analyzing homology of guinea pig hepcidin nucleotide sequence as well as amino acid sequence of full-length preprohepcidin and the biological active hepcidin-25 revealed striking high identity with humans and chimpanzees, while homology to the respective sequences in dog and pig as well as in rodent species like mouse and rat was lower. Thus, guinea pig hepcidin: i) showed the highest homology to human hepcidin sequence when looking to the nucleotide and amino acid sequence of preprohepcidin,

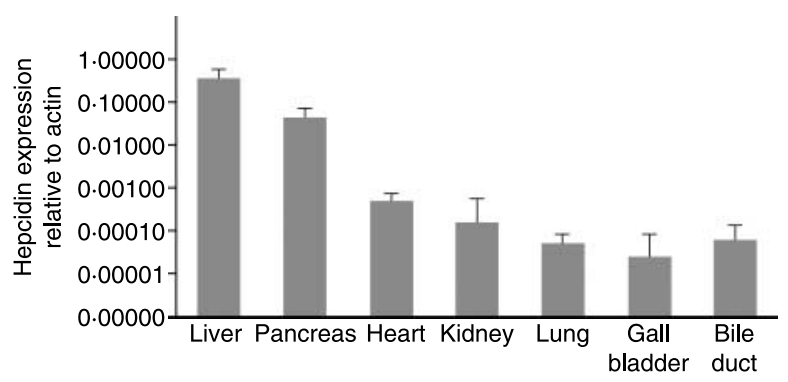

Figure 3 RT-PCR analysis of guinea pig hepcidin gene expression in various tissues. Total RNA $(2 \mu \mathrm{g})$ was reversed transcribed into CDNA and analyzed in SYBR Green based real-time PCR. Results are shown relative to endogenous control actin. Data are the mean \pm s.D. of four analyzed guinea pigs. 


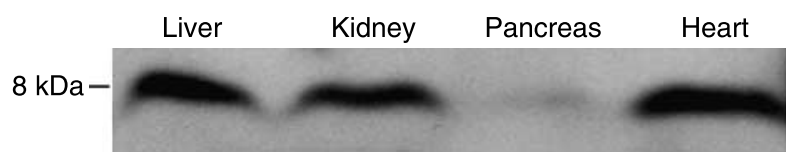

Figure 4 Tissue expression of hepcidin assessed by western blo assay. A total of $50 \mu \mathrm{g}$ total protein from indicated tissue samples was loaded. Specific hepcidin antibody identified an $8 \mathrm{kDa}$ band in probes of guinea pig liver, kidney, pancreas, and heart.

and ii) is the rodent with the hepcidin sequence the most homologous to human. This is confirmed by phylogenetic analysis, but is somehow surprising, because guinea pig, belonging to the group of caviidae, is a rodent and more related to mouse and rat (muridae), than to primates like human and chimpanzee.

The analysis of hepcidin gene expression in guinea pig tissues by quantitative RT-PCR and by immunoblot assays
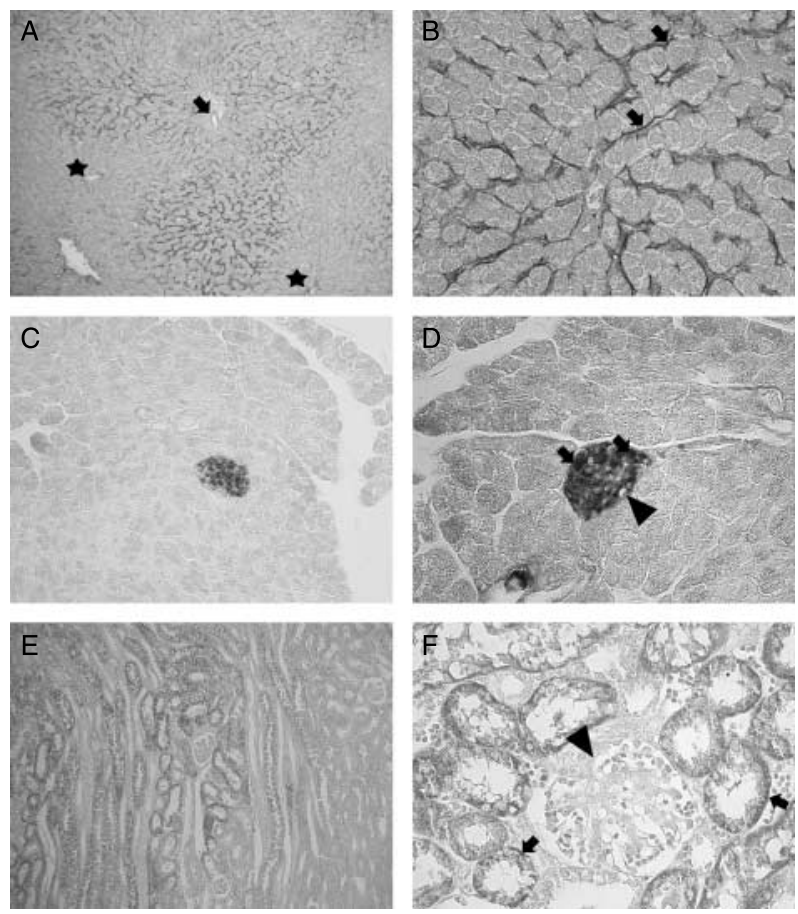

Figure 5 Cellular localization of hepcidin in guinea pig liver $(A$ and $B)$, pancreas (C and D), and kidney ( $E$ and $F)$. The paraffin sections immunostained with the region-specific antibody $\mathrm{EG}(2)-\mathrm{HepN}$ shows distinct immunoreactivity. Magnification $100 \times(A, C$ and $E)$ and $400 \times(B, D$ and $F)$. (A) Zonation of hepcidin staining within hepatic lobules with decreasing immunoreactivity from periportal zones (arrow) towards the central veins (star), where no staining was found. (B) Hepcidin immunoreactivity at the basolateral membrane domain of hepatocytes (arrows). (C) Hepcidin staining in guinea pig pancreas is only found in islets of Langerhans, whereas no staining is found in the exocrinous pancreas. (D) Arrows show hepcidin immunoreactive cells in a Langerhans islet. Note that some cells showed no hepcidin staining (arrow head). ( $E$ and $F$ ) In guinea pig kidney, hepcidin immunoreactivity is located in tubular cells (arrows, in F). Note that there is no hepcidin staining within the glomerulus (arrow head, in F). revealed liver as the major production site. These data are in agreement with the hepcidin tissue distribution in human (Krause et al. 2000, Park et al. 2001), mouse (Pigeon et al. 2001, Ilyin et al. 2003), dog (Fry et al. 2004), and fishes (Shike et al. 2002, 2004, Douglas et al. 2003, Bao et al. 2005, Chen et al. 2005, 2007, Hirono et al. 2005, Kim et al. 2005, 2008, Cuesta et al. 2007). Similarly to previous studies (Kulaksiz et al. 2005, 2008, Merle et al. 2007), we were able to detect hepcidin mRNA and peptide in extrahepatic organs of guinea pig including kidney, heart, and pancreas, albeit at different levels, showing that hepcidin may play a role in extrahepatic organs, too. In the pancreas, only a weak band was identified while the mRNA level was high when compared with other extrahepatic tissues. This may be due to the cellular localization of the peptide (see below), because hepcidin containing pancreatic $\beta$-cells constitute merely a small compartment of the total pancreatic parenchyma.

Determination of cellular hepcidin localization in liver, pancreas, and kidney revealed staining pattern similar to hepcidin distribution observed in human tissues. In the guinea pig liver, hepcidin was localized to hepatocytes within the periportal region, with decreasing immunostaining from portal triads towards the central veins (Kulaksiz et al. 2004), indicating local differences in hepatic hepcidin expression. Hepcidin immunoreactive cells in the guinea pig pancreas were found exclusively in Langerhans islets. In human and rat pancreas, the hepcidin-positive cells were clearly identified as insulin-producing $\beta$-cells by their typical localization within the Langerhans islets and by co-localization of hepcidin and insulin (Kulaksiz et al. 2008), assuming that in the guinea pig the endogenous hepcidin-positive cells are $\beta$-cells, too. In the guinea pig kidney, hepcidin was localized to epithelial cells of renal tubules, while no hepcidin immunoreactivity was observed in the glomerulus. This staining pattern was already described in kidney of human, mouse, and rat (Kulaksiz et al. 2005). In immunoblot analyses, hepcidin was found in rat heart before and using immunofluorescence assays the peptide was located to the cardiomyocytes pronounced at the intercalated disc region in rat heart (Merle et al. 2007). Expression was found to be dependent on hypoxia, suggesting that hepcidin in the heart prevents the cardiomyocytes from hypoxia-induced oxidative stress by elicited free iron. Unfortunately, we were not able to detect hepcidin at the cellular level in the guinea pig heart using immunohistochemical methods, maybe due to technical problems.

To our knowledge, this report is the first to describe the sequence, extrahepatic tissue distribution as well as cellular localization of hepcidin in the guinea pig. Taken together, the results presented here identify the guinea pig as a promising animal research model to study hepcidin and iron metabolism, but further experiments are necessary to determine the regulation of guinea pig hepcidin through iron or iron depletion and inflammatory stimuli. 


\section{Declaration of interest}

Authors declare that there is no conflict of interest.

\section{Funding}

This project was funded by grant of the Deutsche Forschungsgemeinschaft (KU 1253/5-3).

\section{Acknowledgements}

Data concerning the guinea pig hepcidin DNA sequence and the chromosomal localization were provided by the Broad Institute (Cambridge, MA, USA).

\section{References}

Bao B, Peatman E, Li P, He C \& Liu Z 2005 Catfish hepcidin gene is expressed in a wide range of tissues and exhibits tissue specific up-regulation after bacterial infection. Developmental and Comparative Immunology 29 939-950.

Bendtsen JD, Nielsen H, von Heijne G \& Brunak S 2004 Improved prediction of signal peptides: SignalP 3.0. Journal of Molecular Biology 340 783-795.

Chen SL, Xu MY, Ji XS, Yu GC \& Liu Y 2005 Cloning, characterization and expression analysis of hepcidin gene from red sea bream (Chrysophrys major). Antimicrobial Agents and Chemotherapy 49 1608-1612.

Chen SL, Li W, Meng L, Sha ZX, Wang ZJ \& Ren GC 2007 Molecular cloning and expression analysis of a hepcidin antimicrobial peptide gene from turbot (Scophthalmus maximus). Fish and Shellfish Immunology 22 172-181.

Cuesta A, Meseguer J \& Esteban MA 2007 The antimicrobial peptide hepcidin exerts as important role in the innate immunity against bacteria in the bony fish gilthead seabream. Molecular Immunology 45 2333-2342.

Douglas SE, Gallant JW, Ryan SL, Andrew D \& Stephen CMT 2003 Identification and expression analysis of hepcidin-like antimicrobial peptides in bony fish. Developmental and Comparative Immunology 27 589-601

Fein E, Merle U, Ehehalt R, Stremmel W \& Kulaksiz H 2007 Regulation of hepcidin in HepG2 and RINm5F cells. Peptides 28 951-995.

Fry MM, Ligett JL \& Baek SJ 2004 Molecular cloning and expression of canine hepcidin. Veterinary Clinical Pathology 33 223-227.

Ganz T 2003 Hepcidin, a key regulator of iron metabolism and mediator of inflammation. Blood 102 783-788.

Hancook REW \& Lehrer R 1998 Cationic peptides: a new source of antibiotics. TIBTECH 16 82-88.

Hirono I, Hwang JY, Ono Y, Kurobe T, Ohira T, Nozaki R \& Aoki T 2005 Two different types of hepcidins from Japanese flounder Paralichthys olivaceus. FEBS Journal 272 5257-5264.

Hu X, Ward C, Aono S, Lan L, Dykstra C, Kemppainen RJ, Morrison EE \& Shi J 2008 Comparative analysis of Xenopus tropicalis hepcidin I and hepcidin II genes. Gene 426 91-97.

Ilyin G, Courselaud B, Troadec M-B, Pigeon C, Alizadeh M, Leroyer P, Brissot P \& Loréal O 2003 Comparative analysis of mouse hepcidin 1 and 2 genes: evidence for different patterns of expression and co-inducibility during iron-overload. FEBS Letters 542 22-26.

Karolchik D, Kuhn RM, Baertsch R, Barber GP, Clawson H, Diekhans M, Giardine B, Harte RA, Hinrichs AS, Hsu F et al. 2008 The UCSC Genome Browser Database: 2008 update. Nucleic Acids Research 36 D773-D779.

Kent WJ 2002 BLAT - the BLAST-like alignment tool. Genome Research 12 656-664.

Kim YO, Hong SH, Nam BH, Lee JO, Kim KK \& Lee SJ 2005 Molecular cloning and expression analysis of two hepcidin genes from olive flounder Paralichthys olivaceus. Bioscience, Biotechnology, and Biochemistry 69 1411-1414.
Kim YO, Park EM, Nam BH, Kong HJ, Kim WJ \& Lee SJ 2008 Identification and molecular characterization of two hepcidin genes from black rockfish (Sebastes schlegelii). Molecular and Cellular Biochemistry 315 131-136.

Krause A, Neitz S, Mägert HJ, Schulz A, Forssmann WG, Schulz-Knappe P \& Adermann K 2000 LEAP-1, a novel highly disulfide-bonded human peptide, exhibits antimicrobial activity. FEBS Letters $\mathbf{4 8 0}$ 147-150.

Kulaksiz H, Schmid A, Hönscheid M, Ramaswamy A \& Cetin Y 2002 Clara cell impact in air-side activation of CFTR in small pulmonary airways. PNAS 99 6796-6801.

Kulaksiz H, Gehrke SG, Janetzko A, Rost D, Bruckner T, Kallinowski B \& Stremmel W 2004 Prohepcidin: expression and cell specific localisation in the liver and its regulation in hereditary haemochromatosis, chronic renal insufficiency, and renal anaemia. Gut 53 735-743.

Kulaksiz H, Theilig F, Bachmann S, Gehrke SG, Rost D, Janetzko A, Cetin Y \& Stremmel W 2005 The iron-regulatory peptide hormone hepcidin: expression and cellular localization in the mammalian kidney. Journal of Endocrinology 184 361-370.

Kulaksiz H, Fein E, Redecker P, Stremmel W, Adler G \& Cetin Y 2008 Pancreatic beta-cells express hepcidin, an iron-uptake regulatory peptide. Journal of Endocrinology 197 241-249.

Merle U, Fein E, Gehrke SG, Stremmel W \& Kulaksiz H 2007 The iron regulatory peptide hepcidin is expressed in the heart and regulated by hypoxia and inflammation. Endocrinology 148 2663-2668.

Nakayama K 1997 Furin: a mammalian subtilisin/Kex2p-like endoprotease involved in processing of a wide variety of precursor proteins. Biochemical Journal 327 625-635.

Nemeth E, Valore EV, Territo M, Schiller G, Lichtenstein A \& Ganz T 2003 Hepcidin, a putative mediator of anemia of inflammation, is a type II acute-phase protein. Blood 101 2461-2463.

Nemeth E, Rivera S, Gabayan V, Keller C, Taudorf S, Pedersen BK \& Ganz T $2004 a$ IL-6 mediates hypoferremia of inflammation by inducing the synthesis of the iron regulatory hormone hepcidin. Journal of Clinical Investigation 113 1271-1276.

Nemeth E, Tuttle MS, Powelson J, Vaughn MB, Donovan A, Ward DM, Ganz T \& Kaplan J 2004b Hepcidin regulates cellular iron efflux by binding to ferroportin and inducing its internalization. Science 306 2090-2093.

Nicolas G, Bennoun M, Devaux I, Beaumont C, Grandchamp B, Kahn A \& Vaulont S 2001 Lack of hepcidin gene expression and severe tissue iron overload in upstream stimulatory factor 2 (USF2) knockout mice. PNAS 98 $8780-8785$.

Nicolas G, Chauvet C, Viatte L, Danan JL, Bigard X, Devaux I, Beaumont C, Kahn A \& Vaulont S 2002a The gene encoding the iron regulatory peptide hepcidin is regulated by anemia, hypoxia, and inflammation. Journal of Clinical Investigation 110 1037-1044.

Nicolas G, Bennoun M, Porteu A, Mativet S, Beaumont C, Grandchamp B, Sirito M, Sawadogo M, Kahn A \& Vaulont S 2002b Severe iron deficiency anemia in transgenic mice expressing liver hepcidin. PNAS 99 4596-4601.

Park CH, Valore EV, Waring AJ \& Ganz T 2001 Hepcidin, a urinary antimicrobial peptide synthesized in the liver. Journal of Biological Chemistry 276 7806-7810

Pietrangelo A, Caleffi A, Henrion J, Francesca F, Corradini E, Kulaksiz H, Stremmel W, Andreone P \& Garuti C 2005 Juvenile hemochromatosis associated with pathogenic mutations of adult hemochromatosis genes. Gastroenterology 128 470-479.

Pigeon C, Ilyin G, Courseland B, Leroyer P, Turlin B, Brissot P \& Loréal O 2001 A new mouse liver-specific gene, encoding a protein homologous to human antimicrobial peptide hepcidin, is overexpressed during iron overload. Journal of Biological Chemistry 276 7811-7819.

Roetto A, Papanikolaou G, Politou M, Alberti F, Girelli D, Christakis J, Loukopoulos D \& Camaschella C 2003 Mutant antimicrobial peptide hepcidin is associated with severe juvenile hemochromatosis. Nature Genetics 32 21-22.

Saitou N \& Nei M 1987 The neighbor-joining method: a new method for reconstructing phylogenetic trees. Molecular Biology and Evolution 4 $406-425$. 
Shike H, Lauth X, Westerman ME, Ostland VE, Carlberg JM, Van Olst JC, Shimizu C, Bulet P \& Burns JC 2002 Bass hepcidin is a novel antimicrobial peptide induced by bacterial challenge. European Journal of Biochemistry 269 2232-2237.

Shike H, Shimizu C, Lauth X \& Burns JC 2004 Organization and expression analysis of the zebrafish hepcidin gene, an antimicrobial peptide gene conserved among vertebrates. Developmental and Comparative Immunology 28 747-754.

Tamura K, Dudley J, Nei M \& Kumar S 2007 MEGA4: molecular evolutionary genetics analysis (MEGA) software version 4.0. Molecular Biology and Evolution 24 1596-1599.

Thompson JD, Higgins DG \& Gibson TJ 1994 CLUSTAL W: improving the sensitivity of progressive multiple sequence alignment through sequence weighting, position-specific gap penalties and weight matrix choice. Nucleic Acids Research 22 4673-4680.
Valore EV \& Ganz T 2008 Posttranslational processing of hepcidin in human hepatocytes is mediated by the prohormone convertase furin. Blood Cells, Molecules, and Diseases 40 132-138.

Vyoral D \& Petrak J 2005 Hepcidin: a direct link between iron metabolism and immunity. International Journal of Biochemistry and Cell Biology 37 1768-1773.

Weinstein DA, Roy CN, Fleming MD, Loda MF, Wolfsdorf JI \& Andrews NC 2002 Inappropiate expression of hepcidin is associated with iron refractory anemia: implications for the anemia of chronic disease. Blood 100 3776-3781.

Received in final form 9 June 2009

Accepted 24 June 2009

Made available online as an Accepted Preprint 24 June 2009 